\title{
Physico-chemical characteristics and heavy metal concentrations of copper mine wastes in Zambia: implications for pollution risk and restoration
}

\author{
Mutale N. Chileshe $^{1} \cdot$ Stephen Syampungani $^{1} \cdot$ Emma Sandell Festin $^{2} \cdot$ \\ Mulualem Tigabu ${ }^{2} \cdot$ Abolfazl Daneshvar ${ }^{3} \cdot$ Per Christer Odén ${ }^{2}$
}

Received: 17 November 2018/ Accepted: 14 February 2019/Published online: 23 March 2019

(C) The Author(s) 2019

\begin{abstract}
Soil characterization is a vital activity to develop appropriate and effective restoration protocols for mine wastelands while insights into the total content of heavy metals in the soil is an important step in estimating the hazards that the metals may pose to the vital roles of soil in the ecosystem. This study addressed the following research questions: (1) To what extent do the physico-chemical characteristics vary between mine waste sediments and the nearby forest soil? (2) Are the concentrations of heavy metals high enough to be considered as toxic? and (3) Are heavy metals present in mine waste sediments potential sources of pollution? We hypothesized that the physicochemical characteristics of mine waste sediments are less favorably for plant establishment and growth while the concentrations of heavy metals are very high, thus restricting the success of revegetation of mine waste lands. Mine waste sediments were sampled following a diagonal
\end{abstract}

Project funding: This work was supported by the Swedish Science Council (Vetenskapsrådet, C0626501and D0650301).

The online version is available at http://www.springerlink.com

Corresponding editor: Yu Lei.

Mulualem Tigabu

mulualem.tigabu@slu.se

1 School of Natural Resources, Copperbelt University, Box 21692, Kitwe, Zambia

2 Faculty of Forest Sciences, Southern Swedish Forest Research Centre, Swedish University of Agricultural Sciences, Box 49, 23053 Alnarp, Lomma, Sweden

3 Department of Biology, Faculty of Basic Sciences and Engineering, Gonbad Kavous University, Shahid Fallahi Street, Basirat Blvd, Box 163, Gonbad-e-Kavous, Golestan, Iran transect across tailings dams, overburden dump sites and the local forest soil from the top layer $(0-20 \mathrm{~cm})$ using a closed auger. Samples were analyzed for arsenic, barium, lead, cadmium, cobalt, copper, chromium, nickel, vanadium, and zinc as well as for soil physico-chemical properties. The mine waste sediments were dominated by silt whilst the forest soil by sand particles, with significantly high bulk density in the former. Both the forest soil and overburden sediments were acidic than the alkaline tailings dam sediment. Total organic carbon and nitrogen contents were significantly low in mine wasteland substrates but the concentration of $\mathrm{Ca}$ and $\mathrm{Mg}$ were significantly higher in tailings dam substrate than the forest soil. The concentrations of available $\mathrm{P}, \mathrm{K}$ and $\mathrm{Na}$ were similar across sites. The mean concentrations of heavy metals were significantly $(p<0.01)$ higher in mine waste sediments than the forest soil; except for cadmium ( $p=0.213$ ). The order of contamination by heavy metals on the tailings was $\mathrm{Cu}>$ $\mathrm{Co}>\mathrm{Ba}>\mathrm{Ni}>\mathrm{As}>\mathrm{Zn}>\mathrm{Pb}>\mathrm{Cr}>\mathrm{V}>\mathrm{Cd}$, and that on the overburdens was $\mathrm{Cu}>\mathrm{Co}>\mathrm{Ba}>\mathrm{Ni}>\mathrm{Zn}>$ $\mathrm{Cr}>\mathrm{Pb}>\mathrm{V}>\mathrm{As}>\mathrm{Cd}$. The pollution load index (PLI) was nearly twice higher for the tailings dam (8.97) than the overburden (5.84). The findings show that the copper mine wastes (the tailings dams and overburden waste rock sites) are highly contaminated by heavy metals; which, in turn, might pose serious hazards to human health and agricultural productivity. In addition, poor macro-nutrient availability, substrate compaction and soil acidity (particularly on overburden sites) coupled with toxic level of heavy metals would be the main challenges for successful phytostabilization of copper mine wastelands.

Keywords Contamination factors - Overburden material · Phytostabilization · Pollution load index · Tailings dam 


\section{Introduction}

There is a global concern regarding the high input and flow of heavy metals and metalloids in the biosphere; elements which on a global perspective should normally be present in very low concentrations (Monterroso et al. 2014). While heavy metals are present in the environment naturally, anthropogenic activities, such as mining, tend to increase their occurrence to toxic levels. Mining and processing of metal ores, such as copper, can be a significant source of environmental pollution; thereby affecting environmental quality and ecosystem services (Zhuang et al. 2009). In addition, mining causes extensive environmental destruction in the form of alteration of landscape, deterioration of vast land areas, extinction of wildlife and clearance of vegetation (Lima et al. 2016; Ezeaku and Davidson 2008).

Heavy metals are elements that exhibit metallic properties and include the transition metals, the lanthanides, actinides and some metalloids (Gautam et al. 2011). Although some heavy metals, such as iron, boron, manganese, zinc, copper and molybdenum, are micronutrients essential for plant growth, high concentrations of all heavy metals are toxic and are regarded as pollutants (Chehregani et al. 2004). Soils heavily contaminated by heavy metals, such as $\mathrm{Cu}, \mathrm{Pb}, \mathrm{Zn}$ and $\mathrm{Ni}$, restrict plant growth, cause leaf chlorosis and alteration of the activity of many key enzymes of various metabolic pathways. Contaminated soils also adversely affect the number, diversity and activity of soil organisms, inhibiting soil organic matter decomposition and $\mathrm{N}$-mineralization processes (Wong 2003; Gowda et al. 2010).

The waste materials from the abandoned mine or from decommissioned waste sites, when exposed to processes of weathering over time, may lead to development of a soil type referred to as mine soil (Sencindiver and Ammons 2000) which is generally a young soil. The presence of heavy metals in these metalliferous soils in very high concentrations negatively affects the quality of soil and destroys their functional ecosystems (Zhang and Ke 2004); leaving these wastelands devoid of vegetation for extended periods of time. Furthermore, mine wastelands have generally poor water holding capacity, low organic matter content, nutrient deficiency and low microbial activity (O'Dell et al. 2007). Thus, mine waste materials, such as tailings dam and overburdens, are one of the main environmental problems in post-mining landscapes. In the absence of adequate closure management, metalliferous mine tailings and overburden materials pose serious hazards to human health and agricultural productivity through surface or groundwater pollution, offsite contamination via aeolian dispersion and water erosion, and uptake by vegetation and bioaccumulation in food chains (Tutu et al. 2008; Kuter 2013).

Currently, large amounts of mine wastes are of serious environmental concern in Zambia, where there are about 791 million tons of tailings covering 9125 ha of land and 1899 million tons of overburden materials covering 20,646 ha, as well as an estimated 77 million tons of waste rock covering 388 ha and 40 million tons of slag covering 279 ha of land (Sikaundi 2013). Despite the occurrence of huge mine generated wastelands in Southern-Central Africa (Venkateswarlu et al. 2016), little information is available, particularly in Zambia, regarding the physicochemical characteristics as well as the distribution and concentration of heavy metals across these wastelands. Previous studies have mainly focused on heavy metal accumulation and its biological impact (Yabe et al. 2011, 2012; M'kandawire et al. 2012; Kapungwe 2013; Nakayama et al. 2013) and heavy metal accumulation in soils and sediments (Ikenaka et al. 2010).

The objectives of this study were to quantify the heavy metal contamination and pollution load in different mine waste sediments and to characterize their physical and chemical properties. The research questions addressed were: (1) To what extent do the physico-chemical characteristics vary between mine waste sediments and the nearby forest soil?, (2) Are the concentrations of heavy metals high enough to be considered as toxic?, and (3) Are heavy metals present in mine waste sediments potential sources of pollution? We hypothesized that the physico-chemical characteristics of mine waste sediments are less favorably for plant establishment and growth while the concentrations of heavy metals are very high, thus restricting the success of revegetation of mine waste lands. The results from this study will allow identifying factors that limit restoration of post-mining landscape using phytostabilization method, which involves the use of plant species and soil amendment measures to immobilize heavy metals through absorption and accumulation by roots, adsorption onto roots, or precipitation within the rhizosphere (Mendez and Maier 2008; Bolan et al. 2011).

\section{Materials and methods}

\section{Study area}

The study was undertaken on Copper Mine wastelands in Chingola District, Zambia (Fig. 1). The study site is located between longitude and latitude $12^{\circ} 32^{\prime}$ South and $27^{\circ}$ $51^{\prime}$ East and one of the oldest copper mining towns of Zambia. The area receives an average of $1000 \mathrm{~mm}$ of rainfall annually (Environmental Council of Zambia 2000) and has three distinct season; rainy season (November- 


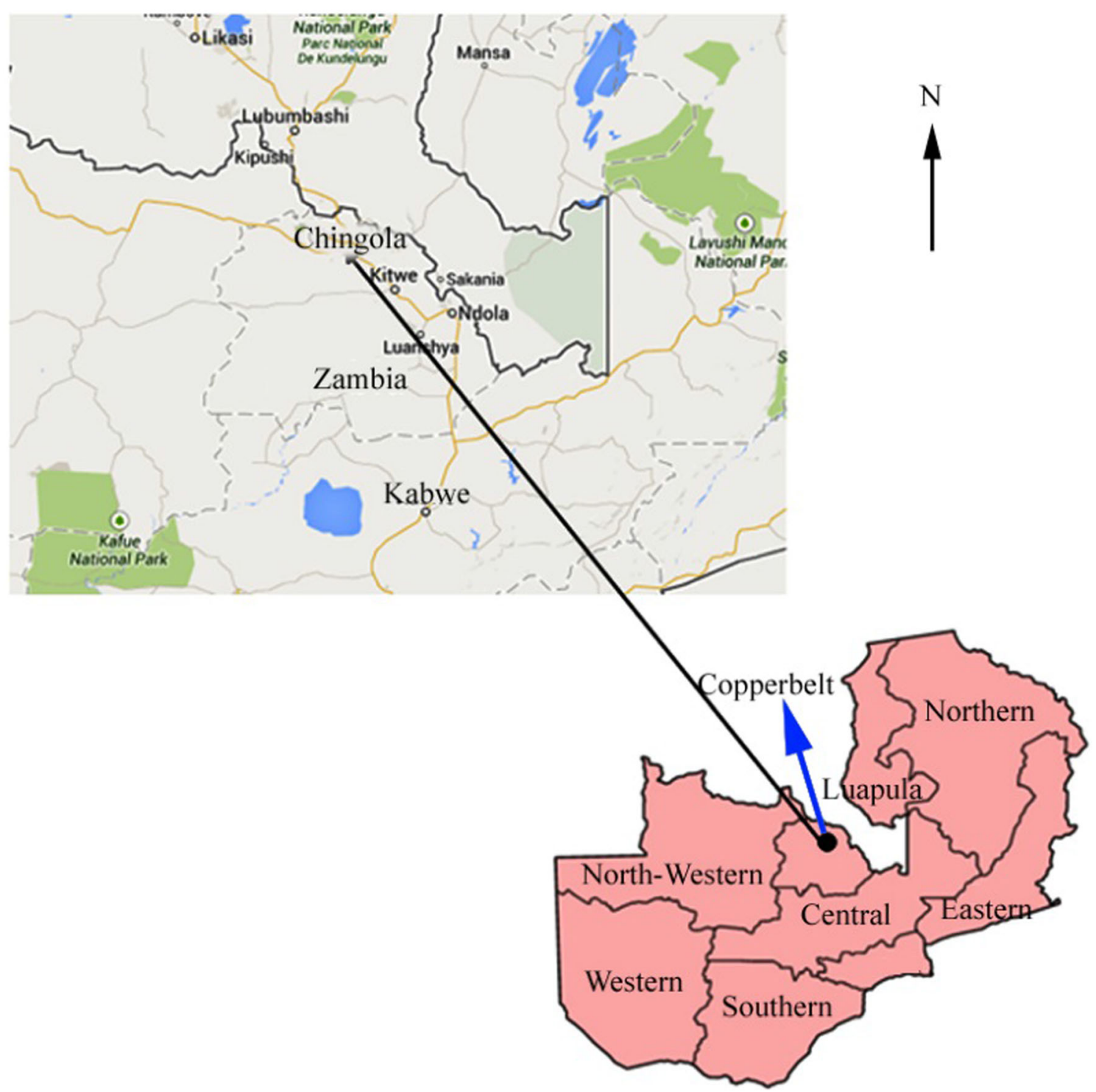

Fig. 1 Map of the study area

April), cool dry season (May-August) and the hot dry season (August-November). Due to the country's elevation, the area usually experiences a subtropical climate with mean monthly temperatures ranging from 15.8 to 15.9 ${ }^{\circ} \mathrm{C}$ in June and July (the coldest months) to $26.3{ }^{\circ} \mathrm{C}$ in October which is the hottest month (Environmental Council of Zambia 2000).

The underlying geology of the area is the mineralized Katanga system and the undifferentiated basement complex of mainly granites, granitic gneisses and migmatites (Environmental Council of Zambia 2000). The soils are of two distinctly different types. In the western part of the area, soils are chromic haplic Ferrasols (according to FAO classification system) which are well drained, deep to very deep yellowish red to strong brown, friable-clayey soils with a high silt/clay ratio and fairly uniform texture throughout. In the eastern part, the chromic haplic Acrisols are the dominant form, which are well drained, deep to very deep yellowish red to strong brown friable loamy to clayey soils having a clear clay increase with depth (Government of the Republic of Zambia 1991). The natural vegetation is pre-dominantly miombo woodland dominated by the genera Brachystegia, Julbernadia and Isoberlina (Syampungani et al. 2011).

\section{Substrate sampling and analyses}

Sampling was performed by following a diagonal transect across selected wastelands (tailings dam and overburden dump sites), and the local forest (control) that was in close proximity to the studied wastelands. A tailings dam is typically an earth-fill embankment dam used to store 
byproducts of mining operations after separating the ore from the gangue while overburden materials include the soil and rock, which are removed in order to gain access to the ore deposits. The wastelands were randomly selected from among the various sites. At every $100 \mathrm{~m}$ interval, five soil samples within $20 \mathrm{~m}$ radius were randomly collected from the top layer $(0-20 \mathrm{~cm})$ using a closed auger, then thoroughly mixed in a bucket to make a composite sample. A total of 12 composite samples were collected from each mine wasteland type, while six samples were collected from the local forest. At every sampling point, $2 \mathrm{~kg}$ of composite sample was collected and stored in a polythene bag. Samples were air dried for $48 \mathrm{~h}$ in the laboratory and sieved through 2-mm sieve for analysis after grinding them with a wooden mortar. The sediments were extracted by acid digestion (Sposito 1989) and further analyzed for arsenic (As), barium (Ba), lead ( $\mathrm{Pd})$, cadmium (Cd), cobalt $(\mathrm{Co})$, copper $(\mathrm{Cu})$, chromium $(\mathrm{Cr})$, nickel $(\mathrm{Ni})$, vanadium (V) and zinc (Zn) using inductively coupled plasma-atomic emission spectrometry (ICP-AES) in a commercial soil lab (Eurofins Environment Sweden AB).

The particle size distribution was determined by the Robinson pipette method (Sheldrick and Wang 1993) while bulk density was determined using volumetric cylinders (5$\mathrm{cm}$ diameter core rings) from the top soil (0-20 cm depth). Total organic carbon content was determined according to the Walkley and Black method (Nelson and Sommers 1982), total N content was measured following the Kjeldahl method (Bremner 1996) and available phosphorus was determined by Bray 1 method (Bray and Kurtz 1945). Exchangeable cations were extracted with $1 \mathrm{~N}$ ammonium acetate at $\mathrm{pH}$ of 7 . Calcium and magnesium were determined by atomic-absorption spectrophotometry, sodium and potassium by flame-emission spectrophotometry. Soil $\mathrm{pH}$ was measured with combined electrodes in a 1:2.5 soil/ water suspension. Percentage base saturation (PBS) was calculated as a ratio of the sum of the charge equivalents of the base cations $\left(\mathrm{Ca}^{2+}, \mathrm{Mg}^{2+}, \mathrm{K}^{+}\right.$and $\left.\mathrm{Na}^{+}\right)$to the $\mathrm{CEC}$ of the soil.

\section{Data analysis}

To examine differences in concentrations of heavy metals and physico-chemical characteristics of substrates collected from the tailings dam, overburden dump and the natural forest sites, One-way ANOVA was performed. The mean concentrations of the heavy metals that exhibited significant difference between sites were compared using Tamhane's T2 for unequal variance $(p<0.05)$. Indices were also applied to assess the heavy metal sediment contamination. To assess the extent of contamination of the tailings and overburden sites by heavy metals, contaminant factor $\left(C_{f}^{i}\right)$ and the degree of contamination $\left(C_{d}\right)$ were computed following Hakanson (1980) as Eqs. 2 and 3:

$C_{f}^{i}=\frac{C_{0-1}^{i}}{C_{n}^{i}}$

$C_{d}=\sum_{i=1}^{n} C_{f}^{i}$

$C_{0-1}^{i}$ is the mean concentration of each metal in the substrate; $C_{n}^{i}$ is the concentration of the metal in unpolluted soil which is the baseline or background value. In our case the arithmetic mean values from the nearby natural forests were used as baseline. These indices were interpreted following Seshan et al. (2010) as follows: (1) low degree of contamination if $C_{f}^{i}<1$ and $C_{d}<7$, (2) moderate degree of contamination if $1<C_{f}^{i}<3$ and $7<C_{d}<14$, (3) considerable degree of contamination if $3<C_{f}^{i}<6$ and $14<C_{d}<28$, and (4) very high degree of contamination if $C_{f}^{i}>6$ and $C_{d}>28$.

The extent of heavy metal pollution from mining wastes were also evaluated using pollution load index (PLI), which was defined as the geometric mean of the concentration factors for the $n$ metals (Tomlinson et al. 1980). The PLI was calculated using Eq. 3:

$P L I=\sqrt[n]{C F_{1} \times C F_{2} \times C F_{3} \times \cdots C F_{n}}$

$C F$ is the concentration factor, calculated as a ratio of the concentrations of the various heavy metals in wastelands to that of the natural forest and $n$ is the number of heavy metals. These indices have been employed in several studies to assess pollution levels in sediments (Seshan et al. 2010) and sewage irrigation (Liu et al. 2005).

\section{Results}

\section{Physico-chemical characteristics}

The textural fractions varied significantly $(p<0.05)$ among sites (Fig. 2), where the silt fraction was higher in the overburdens and the tailing dam substrates (above 50\% in both cases) than in the local forest soil (below 20\%). The sand fraction was higher in the local forest (above 50\%) than in both the tailings dams and the overburden sites (below 40\%). In all the sites, the clay content was below $40 \%$, but still significantly higher in the local forest soil than in mine wasteland substrates. The bulk density also varied significantly $(p<0.05)$ among sites (Table 1$)$. The local forest soil had minimal compaction with a narrow range of bulk density $\left(1.13-1.35 \mathrm{~g} \mathrm{~cm}^{-3}\right)$ compared to the overburdens, which had wider range $\left(1.26-1.82 \mathrm{~g} \mathrm{~cm}^{-3}\right)$. The bulk density of the tailing was still higher than the 


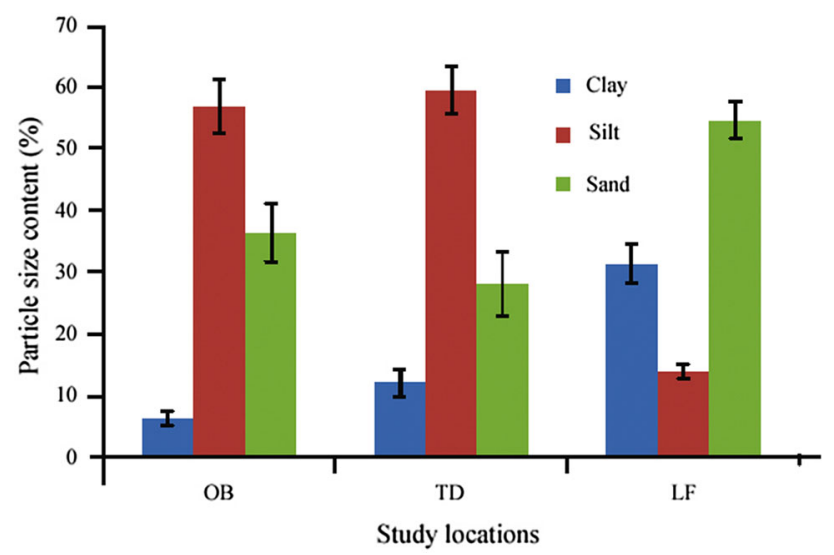

Fig. 2 Textural fractions (\%) in local forest soil (LF), tailings (TD) and overburden $(\mathrm{OB})$ substrates (mean $\pm \mathrm{SE}$ )

forest soil but remained statistically similar to that of the overburdens.

The $\mathrm{pH}$ of mine wasteland substrates significantly differed from each other and the local forest soil (Table 1). Both the local forest soil and overburden substrate were more acidic than the tailings dam substrate, which was alkaline. The total organic carbon and nitrogen contents of the local forest soil were significantly higher than that of the mine wastelands whereas the available $\mathrm{P}$ content remained the same across the sites (Table 1). With regard to exchangeable cations, significant differences among sites were not detected for monovalent cations ( $\mathrm{K}$ and $\mathrm{Na}$ ), but divalent cations $(\mathrm{Ca}$ and $\mathrm{Mg}$ ) were significantly higher in tailings substrate than overburden substrate and the local forest soil (Table 1). Even the overburden substrate had significantly higher $\mathrm{Ca}$ and $\mathrm{Mg}$ contents than the local forest soil. The base saturation exhibited similar increasing trend as divalent cations from the local forest soil to tailings substrate.

\section{Heavy metal concentrations}

The mean concentration of heavy metals differed significantly $(p<0.01)$ among sites except $\mathrm{Cd}(p=0.213)$. In comparison to the local forest soil which was being used as baseline or reference samples, the mine soils had elevated levels of potentially toxic heavy metals (Fig. 3). However, the concentrations varied greatly depending on the mine wasteland. The substrates from the tailings dam contained the highest concentrations of $\mathrm{As}, \mathrm{Pb}, \mathrm{Co}$ and $\mathrm{Cu}$ compared with substrates from overburden materials and adjacent forest soil. Substrates from overburden material had the highest concentrations of $\mathrm{Ba}, \mathrm{Cr}$ and $\mathrm{V}$ compared with substrates from tailings dam and forest soils. The concentrations of $\mathrm{Ni}$ and $\mathrm{Zn}$ did not differ between tailings dam and overburden materials, but were significantly higher than the adjacent forest soils. Among the heavy metals analyzed in the present study, the concentration of $\mathrm{Cu}$ was the highest in the mine wasteland (12233.3 $\pm 1746.9 \mathrm{mg} \mathrm{kg}^{-1}$ for tailings dam; and $7411.7 \pm 1317.5 \mathrm{mg} \mathrm{kg}^{-1}$ for the overburden) while the concentration of $\mathrm{Cd}$ was the lowest $\left(0.60 \pm 0.25 \mathrm{mg} \mathrm{kg}^{-1}\right.$ for tailings dam; $0.25 \pm 0.13 \mathrm{mg} \mathrm{kg}^{-1}$ for overburden); and the later did not differ significantly from the forest soil $\left(0.78 \pm 0.13 \mathrm{mg} \mathrm{kg}^{-1}\right)$.

\section{Degree of contamination and pollution}

The degree of contamination by each heavy metal was analyzed for tailings dam and overburden; and the results showed a very high degree of contamination of the tailings dam by all heavy metals except cadmium, chromium and vanadium, which had low to moderate degree of contamination (Table 2). For the overburden, the degree of contamination was low for cadmium, moderate for arsenic, lead, chromium, and vanadium and very high for barium, cobalt, copper, nickel and zinc (Table 2). The overall degree of contamination was nearly twice higher for the tailings dam than the overburden materials. Similarly, the pollution load index was 1.5 times higher for the tailings dam than the overburden materials (Table 2).

\section{Discussion}

Soil compaction, poor macro-nutrient availability and soil acidity (particularly on overburden sites) are typical features of mine wasteland sediments. With regard to particle size distribution, the mine wasteland substrates are mainly composed of silt and sand particles with very little clay while the local forest soil has more sand and clay (Fig. 2). The high silt and sand contents on the mine wastes imply the substrates have low aggregates and nutrient binding capacity (Brady and Weil 1996), and their capacity to retain water is low. In comparison, the local forest soil has more sand and clay than silt. The high rainfall that the area receivess every year may have leached the clay particles. The textural compositions of the soil have an effect on the ability of the soil to retain the nutrients. Generally, finer soils/sediments that have more clay or silt have high retention ability than coarse soils/sediments (Witheetrirong et al. 2011). This could explain why the total organic carbon and nitrogen contents of tailings and overburden substrates are slightly lower than the local forest soil, which has more clay texture in addition to the vegetation that boosts these nutrients through litter fall. The bulk density of tailings substrate and local forest soil is within the normal range of 1.1-1.6 $\mathrm{g} \mathrm{cm}^{-3}$ (Aubertin and Kardos 1965) compared with the overburden substrate with wider 


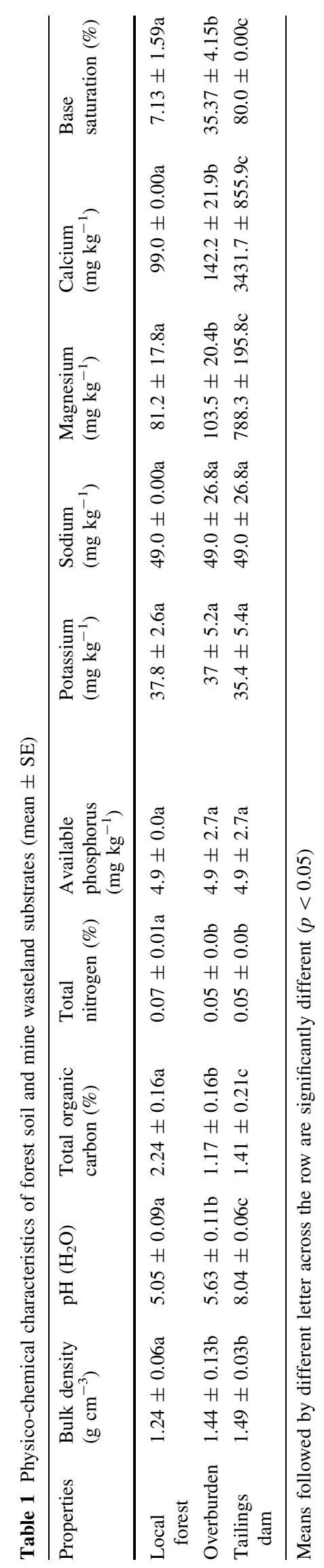




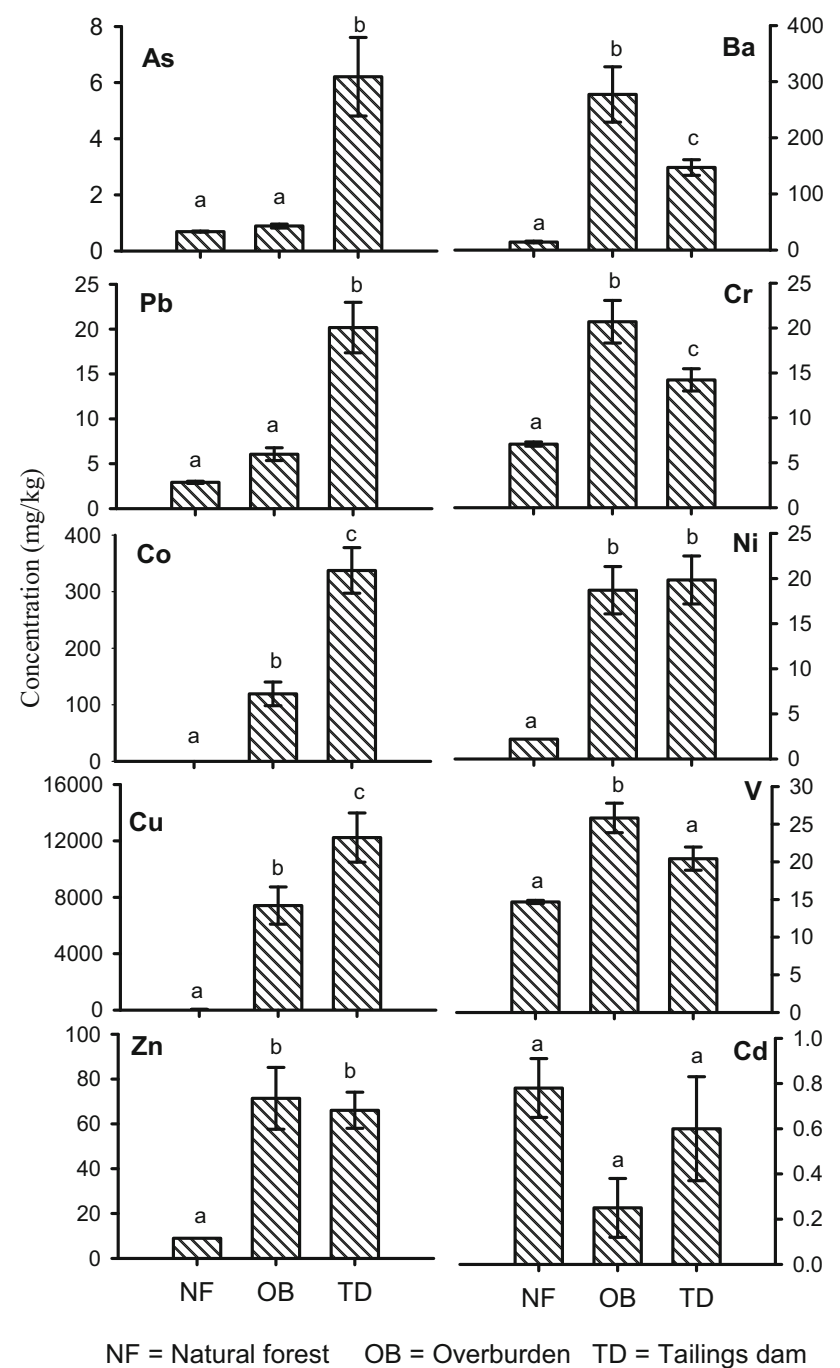

Fig. 3 Concentrations of heavy metals in local forest soil and mine waste sediments (mean $\pm \mathrm{SE}$ ). Bars with different letter are significantly different $(p<0.05)$

range (Table 1). The high bulk density may most likely have been influenced by the use of machinery during deposition of waste, and also due to the fact that mine soils are young soils that are made up of undifferentiated material. The compacted overburden substrate would be a challenge for establishment and growth of plants as it restricts root penetration especially for deep rooted plants (Thompson and Jansen 1987).

The mine wasteland substrates had low $\mathrm{pH}$, particularly for the overburden (Table 1), which is a characteristic of most sulphide ore mine soils (Wong et al. 1999). The high $\mathrm{pH}$ value for the tailings dam compared with the overburden was due to the addition of lime into the effluent prior to discharging by the mining company in an effort to reduce soil acidity and encourage colonization of autochthonous species. Soil $\mathrm{pH}$ plays a crucial role in influencing other soil processes; e.g. those connected with nutrient availability and the mobility of potentially toxic elements such as heavy metals (Bussinow et al. 2012). Under acidic conditions, heavy metals easily dissolve to form toxic concentrations, which may hinder plant growth (Donahue et al. 1990; Das and Maiti 2005). The low pH and high rainfall in the area can offer a favorable environment for the heavy metals to easily dissolve; thus making them to occur at high concentrations in the mine waste substrates (Ciftci et al. 2005). The availability of macro-nutrient also varied between the local forest soil and mine wasteland substrates. The potassium and sodium contents were low across all studied sites whilst the calcium and magnesium contents were considerably higher in mine waste substrates than in the forest soil. One possible explanation for this would be the fact that the Zambian soils are generally of low potassium content (Mashuta et al. 2010). The other would be the possibility that monovalent cations ( $\mathrm{K}$ and $\mathrm{Na}$ ) might have leached from the system substantially while the divalent cations $(\mathrm{Ca}$ and $\mathrm{Mg})$ are strongly adsorbed to soil particles at increasing soil moisture content during the rainy season. Furthermore, the addition of lime into the effluent by the mining company would attribute to high content of $\mathrm{Ca}$ in mine waste substrates.

The Copperbelt Province of Zambia is generally rich in copper and therefore the soils are generally expected to have high concentration of copper. The results show the occurrence of high concentrations of heavy metals in mine wasteland substrates compared to the local forest soil (Fig. 3). High concentrations of heavy metals in mining generated wasteland soils have been observed in many parts of the world; e.g. Iran (Khorasanipour et al. 2011; Ghaderian and Ravandi 2013), China (Li et al. 2007), Hong Kong (Wong 2003) and France (Remon et al. 2005). This is typical of most mine wasteland sediments and areas rich in minerals (Khorasanipour et al. 2011). According to Adriano (2001), an average global value for total $\mathrm{Cu}$ in uncontaminated soils is about $30 \mu \mathrm{g} \mathrm{g}^{-1}$, while for $\mathrm{Zn}$ $80-120 \mu \mathrm{g} \mathrm{g}^{-1}$. Similarly, the global baseline for other metals in uncontaminated soils is $20 \mu \mathrm{g} \mathrm{g}^{-1}$ for $\mathrm{Pb}$ (Kabata-Pendias and Pendias 1992), $100 \mu \mathrm{g} \mathrm{g}^{-1}$ for Ni (Ross 1994), $2-50 \mathrm{mg} \mathrm{g}^{-1}$ for $\mathrm{Cr}$ (Addo et al. 2012) and $0.01 \mathrm{mg} \mathrm{kg}^{-1}$ for Cd (World Health Organization 2006). Thus, all the heavy metals in the studied mine wasteland can be considered as contamination, except for cadmium, which is generally believed to occur in low concentrations in nature (Wild 1993; James and Brown 2009). It has been shown that heavy metal pollution in either soils or sediments is strongly associated with geological differences (Ikenaka et al. 2010).

In the present study, the concentration of $\mathrm{Cu}$ was substantially higher in the mine wasteland substrates than in the forest soil (Fig. 3). And in comparison to other areas, 
Table 2 Contaminant factor, overall degree of contamination and pollution load index for different heavy metals on tailings dam and overburden sites

\begin{tabular}{lccl}
\hline Metals & \multicolumn{2}{c}{ Contamination factor } & Contamination degree (in tailings/overburden) \\
\cline { 2 - 4 } & Tailings dam & Overburden & \\
\hline Arsenic & 8.95 & 1.28 & Very high/moderate \\
Barium & 10.26 & 19.34 & Very high/very high \\
Lead & 6.88 & 2.07 & Very high/moderate \\
Cadmium & 0.77 & 0.32 & Low/low \\
Cobalt & 153.41 & 54.2 & Very high/very high \\
Copper & 242.24 & 146.76 & Very high/very high \\
Chromium & 2.01 & 2.93 & Moderate/moderate \\
Nickel & 9.02 & 8.5 & Very high/very high \\
Vanadium & 1.39 & 1.76 & Moderate/moderate \\
Zinc & 7.34 & 7.93 & Very high/very high \\
Overall degree of contamination & 442.3 & 245.1 & \\
Pollution load index & 8.97 & 5.84 & \\
\hline
\end{tabular}

Note that the concentrations of heavy metals in the forest soil are baseline value for computing contamination factor

the concentration of $\mathrm{Cu}$ in the mine wastelands is slightly higher than values reported from the Monarch south tailings in Botswana with copper concentration ranging from 865 to $2125 \mathrm{mg} \mathrm{kg}^{-1}$ (Vogel and Kasper 2002), soils around an abandoned mine site in south west Spain with $2874 \mathrm{mg} \mathrm{kg}^{-1} \mathrm{Cu}$ (Fernández-Cadena et al. 2014), in an abandoned $\mathrm{Cu}$ mine site in northeastern Brazil with concentration ranging from 3601 to $9601 \mathrm{mg} \mathrm{kg}^{-1}$ in the bulk soils (Perlatti et al. 2015). The high $\mathrm{Cu}$ concentration in the present study may be attributed to the mineralogy of the studied sites and the processing efficiency. The current mining technology used in Zambia allows for extraction of copper to maximum of $40 \%$ from the ore materials. Furthermore, processing of ore concentration in the past was only applicable to copper sulphide although copper ore is a mixture of copper sulphide and copper oxide (pers.com, Environmental coordinator for Konkola Copper Mines). Thus, copper oxide was being lost to the tailings and therefore became part of the heavy metals in the tailings. This also applies to other non-target metals (iron, manganese, lead etc.) that could be present in the ore and disposed as waste to the tailings dams.

The concentrations of heavy metals also show great variations among sites, for example the mean concentration of copper was $12237.3 \pm 1746.9 \mathrm{mg} \mathrm{kg}^{-1}$ on the tailing, $7411.7 \pm 1317.5 \mathrm{mg} \mathrm{kg}^{-1}$ on the overburden and $50.5 \pm 3.8 \mathrm{mg} \mathrm{kg}^{-1}$ on the local forests. For lead, the concentration was $20.2 \pm 2.8 \mathrm{mg} \mathrm{kg}^{-1}$, $6.1 \pm 0.7 \mathrm{mg} \mathrm{kg}^{-1}$ and $2.9 \pm 0.1 \mathrm{mg} \mathrm{kg}^{-1}$ on the tailing, overburden and forest soil, respectively. These concentrations on the studied mine waste substrates are several times higher than in the local forest. This scenario is common for all the heavy metals studied except cadmium. The differences may be attributed to the fact that tailings and waste rock are processed differently, while soils in the local forest are undisturbed. Our findings in terms of heavy metal concentrations are within the levels reported by other scientists (Kř́ibek et al. 2010; Ettler et al. 2012; Sracek 2015).

The total concentrations of the studied heavy metals provide insight to the extent of their contamination and pollution levels. To highlight the degree and extent of contamination, single and integrated indices were used. The indices used in this study showed that the tailing and overburden substrates are highly polluted with pollution load index of 8.97 and 5.84, respectively (Table 2). While the contaminant factors for all metals with an exception of $\mathrm{Cd}$ indicated moderate to very high contamination degree for both the tailings and the overburdens (Table 2). The overall contamination of the sites studied based on the contamination factor indicates a difference in the contamination levels for some metals (Table 2). The contamination on the tailing follows the order from the highest to the lowest; $\mathrm{Cu}>\mathrm{Co}>\mathrm{Ba}>\mathrm{Ni}>\mathrm{As}>\mathrm{Zn}>\mathrm{Pb}>\mathrm{Cr}>$ $\mathrm{V}>\mathrm{Cd}$; whereas the contamination of heavy metals on the overburdens from the highest to the lowest follows the order; $\mathrm{Cu}>\mathrm{Co}>\mathrm{Ba}>\mathrm{Ni}>\mathrm{Zn}>\mathrm{Cr}>\mathrm{Pb}>\mathrm{V}>$ As $>\mathrm{Cd}$. Arsenic and Lead show high contamination on the substrates of the tailings dams and moderate contamination on the overburden materials. In studies done elsewhere, similar indices have been used in the assessment of heavy metal contamination of either soil or water (Nikolaidis et al. 2010; Nweke and UKpai 2016). As a whole the pollution load index exceeds 1 by a great margin on both the tailings dams and the overburden materials, which is an 
indication of the loss of the quality of young developing soil (Seshan et al. 2010). Thus, metalliferous mine tailings and overburden materials restrict growth for all but the most metal-tolerant plants (Wong 2003); leaving mine wastelands devoid of vegetation for extended period of time.

\section{Conclusion and implications}

Insights into the total content of heavy metals in the soil is an important step in estimating the hazards that the metals may pose to the vital roles of soil in the ecosystem and also in comparison with the quality of set standards. The findings from the present study reveal that the copper mine wastes (the tailings dams and overburden waste rock sites) are highly contaminated by heavy metals. This, in turn, might pose serious hazards to human health and agricultural productivity through surface or groundwater pollution, offsite contamination via aeolian dispersion and water erosion, and uptake by vegetation and bioaccumulation in food chains. For instance, a study made to discriminate between lithogenic and anthropogenic sources of metals and sulphur in soils of central and northern Zambia (Kříbek et al. 2010) reported very high concentrations of heavy metals in dust samples from areas surrounding mining operations including slag and tailing deposits. The high level of heavy metal pollution calls for immediate attention, such as metal attenuation measures, to reduce contamination of the surrounding environment and the health risk to which the nearby community will be exposed.

Soil characterization is a vital activity to develop appropriate and effective restoration protocols for mine wastelands. Developing re-vegetation protocols based on information obtained from ecosystem characterization of the sites earmarked for restoration can make the effort successful. In the present study, soil compaction, poor macro-nutrient availability and soil acidity (particularly on overburden sites) coupled with toxic level of heavy metals would be the main challenges for successful phytostabilization of copper mine wastelands. Thus, site amendment measures, such soil scarification, application of biochar and manure, should be considered to modify the mobility and uptake of heavy metals and to enhance growth performance of species prior to planting on these sites. Emerging evidence showed that addition of biochar and biosolid to soils contaminated by heavy metal is effective in immobilization of the metals (Ahmad et al. 2017) and ameliorate the nitrogen and phosphorus deficiencies of mine spoil to support better survival and growth of reintroduced native species (Nussbaumer et al. 2016). As a whole, the knowledge gained from this study provides a baseline for developing environmental guidelines, suggestions for concomitantly modifying the mobility and uptake of heavy metals from copper mine wastelands and ensure the success of phytostabilization efforts.

Acknowledgements The authors would like to thank the Swedish Science Council for funding field work (Vetenskapsrådet, C0626501and D0650301). Additionally, the Environmental Manager and Environmental Coordinator for Konkola Copper Mines are thanked for their support during our field work.

Open Access This article is distributed under the terms of the Creative Commons Attribution 4.0 International License (http://crea tivecommons.org/licenses/by/4.0/), which permits unrestricted use, distribution, and reproduction in any medium, provided you give appropriate credit to the original author(s) and the source, provide a link to the Creative Commons license, and indicate if changes were made.

\section{References}

Addo MA, Darko EO, Gordon C, Nyarko BJB, Gbadago JK, Nyarko E, Affum HA, Botwe BO (2012) Evaluation of heavy metals contamination of soil and vegetation in the vicinity of a cement factory in the Volta region, Ghana. Int J Sci Technol 2(1):40-50

Adriano DC (2001) Trace elements in terrestrial environments: biogeochemistry, bioavailability and risks of metals. Springer, New York

Ahmad M, Lee SS, Lee SE, Al-Wabel MI, Tsang DCW, Ok YS (2017) Biochar-induced changes in soil properties affected immobilization/mobilization of metals/metalloids in contaminated soils. J Soils Sediments 17:717-730

Aubertin MG, Kardos TL (1965) Root growth through porous media under controlled conditions. Soil sci Am Proc 29:290-293

Bolan NS, Park JH, Robinson B, Naidu R, Huh KY (2011) Phytostabilization: a green approach to contaminant containment. Adv Agron 112:145-204

Brady NC, Weil RR (1996) The nature and properties of soils. Prentice Hall Inc, New Jersey

Bray RH, Kurtz LT (1945) Determination of total, organic and available forms of phosphorus in soils. Soil Sci 59:39-45

Bremner JM (1996) Nitrogen total. In: Sparks (ed) Methods of soil analysis Part 3 chemical methods. Soil Science Society of America Inc. \& American Society of Agronomy Inc., Madison, pp 1085-1121

Bussinow M, Sarapatka B, Dlapa P (2012) Chemical degradation of forest soil as a result of polymetallic ore mining activities. Polish J Environ Stud 21(6):1551-1561

Chehregani A, Malayeri B, Golmohammadi R (2004) Effects of heavy metals on the developmental stages of ovules and embryonic sacs in Euphorbia cheirandenia. Pak J Biol Sci 8:622-625

Ciftci E, Kolayli H, Tokel S (2005) Lead-Arsenic soil geochemical study as an exploration guide over the kill volcanogenic massive sulfide deposit, Northeastern Turkey. J Geochem Explor 86(1):49-59

Das M, Maiti SK (2005) Metal mine waste and phytoremediation. Asian J Water Environ Pollut 4(1):169-176

Donahue RL, Miller RW, Shickluna JC (1990) Soils: an introduction to soils and plant growth. Prentice-Hall, New Delhi

Environmental Council of Zambia (2000) State of the environment in Zambia. Environmental Council of Zambia, Lusaka

Ettler V, Kř́bek B, Majer V, Knésl I, Mihaljevič M (2012) Differences in the bioaccessibility of metals/metalloids in soils 
from mining and smelting areas (Copperbelt, Zambia). J Geochem Explor 113(1):68-75

Ezeaku PI, Davidson A (2008) Analytical situations of land degradation and sustainable management strategies in Africa. J Agri Soc Sci 4:42-52

Fernández-Cadena JC, Andrade S, Silva-Coello CL, De la Iglesia R (2014) Heavy metal concentration in mangrove surface sediments from the north-west coast of South America. Marine Pollut Bull 82:221-226

Gautam N, Gupta R, Mishra A, Singh R (2011) Heavy metals and living systems: an overview. Indian J Pharmacol 43(3):246-253

Ghaderian SM, Ravandi AAG (2013) Accumulation of copper and other heavy metals by plants growing on Sarcheshmeh copper mining area, Iran. J Geochem Explor 123:25-32

Government of the Republic of Zambia (1991) Exploratory soils map of Zambia. Ministry of Agriculture, Survey Department, Lusaka

Gowda SS, Reddy MR, Govila PK (2010) Assessment of heavy metal contamination in soils at Jajmau (Kanpur) and Unnao Industrial areas of the Ganga Plain, Uttar Pradesh, India. J Hazard Mater 174:113-121

Hakanson L (1980) Ecological risk index for aquatic pollution control. A sedimentological approach. Water Res 14(5):975-1001

Ikenaka Y, Nakayama SMM, Muzandu K, Choongo K, Teraoka H, Mizuno N, Ishizuka M (2010) Heavy metal contamination of soil and sediment in Zambia. Afr $\mathbf{J}$ Environ Sci Technol 4(11):729-739

James S, Brown J (2009) Effects of biphenyl-A and other endocrine disruptors compared with abnormalities of schizophrenia: an endocrine disruption theory of schizophrenia. Schizophr Bull 35(1):256-278

Kabata-Pendias A, Pendias H (1992) Trace elements in soils and plants. CRC Press Inc, Florida

Kapungwe ME (2013) Heavy metal contaminated water, soils and crops in Peri urban wastewater irrigation farming in Mufulira and Kafue towns in Zambia. J Geogr Geol 5(2):55-72

Khorasanipour AM, Majid H, Tangestani A, RezaNaseh B, Hajmohammadi H (2011) Hydrochemistry, mineralogy and chemical fraction of mine and processing wastes, associated with porphyry copper mines: a case study from the Sarcheshmeh mine, Iran. Appl Geochem 26:714-730

Kř́bek B, Majer V, Veselovský F, Nyambe I (2010) Discrimination of lithogenic and anthropogenic sources of metals and sulphur in soils of the central-northern part of the Zambian Copperbelt Mining District: a topsoil versus subsurface soil concept. J Geochem Explor 104(3):69-86

Kuter N (2013) Reclamation of degraded landscapes due to opencast mining, advances in landscape architecture. http://www.intecho pen.com/books/advances-in-landscape-architecture/reclamationof-degraded-landscapes-due-to-opencast-mining. Accessed 14 Sept 2018.

Li MS, Luo YP, Su ZY (2007) Heavy metal concentrations in soils and plant accumulation in a restored manganese mineland in Guangxi, South China. Environ Pollut 147:168-175

Lima AT, Mitchell K, O'Connell DW, Verhoeven J, Van Cappellen P (2016) The legacy of surface mining: remediation, restoration, reclamation and rehabilitation. Environ Sci Policy 66:227-233

Liu WH, Zhao ZJ, Ouyang ZY, Solderland L, Liu HG (2005) Impacts of sewage irrigation on heavy Metal distribution and contamination in Beijing, China. Environ Int 31:805-812

Mashuta K, Lusapi J, Kamboyi V (2010) Baseline soil mineralogy study of tailings dump 52 at Nkana mine site. Ministry of Agriculture and Co-operatives, Zambia

Mendez MO, Maier RM (2008) Phytostabilization of mine tailings in arid and semiarid environments-an emerging remediation technology. Environ Health Perspect 116:278-283
M'kandawire E, Syakalima M, Muzandu K, Pandey G, Simuunza M, Nakayama SMMS, Kawai KY, Ikenaka Y, Ishizuka M (2012) The nucleotide sequence of metallothioneins (MT) in liver of the Kafue lechwe (Kobus lechwe kafuensis) and their potential as biomarkers of heavy metal pollution of the Kafue River. Gene 506(2):310-316

Monterroso C, Rodríguez F, Chaves R, Diez J, Becerra-Castro C, Kidd SP, Macías F (2014) Heavy metal distribution in the mine soils and plants growing in $\mathrm{ab} / \mathrm{Zn}$ mining area in NW Spain. Appl Geochem 44:3-11

Nakayama MMS, Ikenaka Y, Hamada K, Muzandu K, Choongo K, Yabe J, Umemura T, Ishizuka M (2013) Accumulation and biological effects of metals in wild rats in mining areas of Zambia. Environ Monit Assess 185(6):4907-4918

Nelson DW, Sommers LE (1982) Total carbon, organic carbon, and organic matter. In: Page AL (ed) Methods of soil analysis, Part 2, chemical andmicrobiological properties. American Society of Agronomy, Inc. \& Soil Science Society of America Inc., Madison, pp 539-579

Nikolaidis C, Zafiriadis I, Mathioudakis V, Constantinidis T (2010) Heavy metal pollution associated with an abandoned lead-zinc mine in the Kirki region NE Greece. Bull Environ Contam Toxicol 85(3):307-312

Nussbaumer Y, Cole MA, Offler CE, Patrick JW (2016) Identifying and ameliorating nutrient limitations to reconstructing a forest ecosystem on mined land. Restor Ecol 24:202-211

Nweke OM, UKpai NS (2016) Use of enrichment, ecological risk and contamination factors with geoaccumulation indexes to evaluate heavy metal contents in the soils around Ameka mining area, South of Abakaliki, Nigeria. JGEESI 5(4):1-13

O’Dell R, Silk W, Green P, Claassen V (2007) Compost amendment of $\mathrm{Cu}-\mathrm{Zn}$ minespoil reduces toxic bioavailable heavy metal concentrations and promotes establishment and biomass production of Bromus carinatus (Hook and Arn.). Environ Pollut 148:115-124

Perlatti F, Ferreira TO, Romero RE, Costa MCG, Otero XL (2015) Copper accumulation and changes in soil physical-chemical properties promoted by native plants in an abandoned mine site in northeastern Brazil: implications for restoration of mine sites. Ecol Eng 82:103-111

Remon E, Bouchardonb J-L, Corniera B, Guyb B, Leclerca J-C, Faure O (2005) Soil characteristics, heavy metal availability and vegetation recovery at a former metallurgical landfill: implications in risk assessment and site restoration. Environ Pollut 137:316-323

Ross SM (1994) Sources and forms of potentially toxic metals in soilplant systems. In: Ross SM (ed) Toxic metals in soil-plant systems. Wiley, Chichester, pp 3-26

Sencindiver JC, Ammons JT (2000) Mine soils Genesis and Classification. In: Barnhisel RI, Darmody RG, Daniels WL (eds) Reclamation of drastically disturbed lands. Am Soc Agron, Agronomy Series, $\mathrm{p} 41$

Seshan BRR, Natesan U, Deepthi K (2010) Geochemical and Statistical approach for Evaluation of heavy metal pollution in core sediments in south east coast of India. Int $\mathrm{J}$ Environ Sci Technol 7(2):291-306

Sheldrick BH, Wang C (1993) Particle Size Distribution. In: Carter MR (ed) Soil sampling and methods of analysis, Canadian Society of Soil Science. Lewis Publishers, Ann Arbor

Sikaundi G (2013) Copper mining industry in Zambia: environmental challenges. http://unstats.un.org/unsd/environment. Accessed 6 Sept 2016

Sposito G (1989) The chemistry of soils. Oxford University Press, New York

Sracek O (2015) Formation of secondary hematite and its role in attenuation of contaminants at mine tailings: review and 
comparison of sites in Zambia and Namibia. Front Environ Sci 2:64-75

Syampungani S, Geldenhuys CJ, Chirwa P (2011) Miombo woodland utilization and management, and impact perception among stakeholders in Zambia: a call for policy change in Southern Africa. J Nat Res Policy Res 3(2):163-181

Thompson PJ, Jansen JI (1987) Penetrometer resistance and bulk density as parameters for predicting root system performance in mine soils. Soil Sci Soc Am J 51:1288-1293

Tomlinson DC, Wilson JG, Harris CR, Jeffery DW (1980) Problems in the assessment of heavy metals levels in estuaries and the formation of a pollution index. Helgol Wiss Meeresunters 33:566-575

Tutu H, McCarthy TS, Cukrowska E (2008) The chemical characteristics of acid mine drainage with particular reference to sources, distribution and remediation: the Witwatersrand Basin, South Africa as a case study. Appl Geochem 23:3666-3684

Venkateswarlu K, Nirola R, Kuppusamy S, Thavamani P, Naidu R, Megharaj M (2016) Abandoned metalliferous mines: ecological impacts and potential approaches for reclamation. Rev Environ Sci Biotechnol 15:327-354

Vogel H, Kasper B (2002) Mine soils on abandoned gold mine tailing in Francistown North-East District, Republic of Botswana. http:// www.limpopo.riverawarenesskit.org/LIMPOPORAK_COM/_ SYSTEM/DMSSTORAGE/3471EN/MINE_SOILS_FTOWN_ SEC.PDF. Accessed 17 Feb 2017

Wild A (1993) Soils and the Environment. Cambridge University Press, Cambridge

Witheetrirong Y, Tripathi NK, Tipdecho T, Parkpian P (2011) Estimation of the effect of soil texture on nitrate-nitrogen content in groundwater using optical remote sensing. Int J Environ Res Public Health 8(8):3416-3436

Wong MH (2003) Ecological restoration of mine degraded soils, with emphasis on metal contaminated soils. Chemosphere 50:775-780

Wong JWC, Chen Q, Zhang FS, Wong MH, Baker AJM (1999) Phytostabilization of mimicked Cadmium contaminated soil with lime amendment. In: Wenzel WW (ed) Biogeochemistry of trace elements, international conference, Vienna, Austria

World Health Organization (2006) World reference base for heavy metals permissible limits for soil, World Health Organization

Yabe J, Nakayama MMS, Ikenaka Y, Muzandu K, Ishizuka M, Umemura T (2011) Uptake of lead, cadmium and other metals in the liver and kidneys of cattle near a lead-zinc mine in Kabwe, Zambia. Environ Toxicol Chem 30(8):1892-1897

Yabe J, Nakayama MMS, Ikenaka Y, Muzandu K, Ishizuka M, Umemura $T$ (2012) Accumulation of metals in the liver and kidneys of cattle from agricultural areas in Lusaka, Zambia. J Vet Med Sci 74(10):1345-1347

Zhang MK, Ke ZX (2004) Copper and Zinc enrichment in the different size fractions of organic matter from polluted soils. Pedosphere 14(1):27-36

Zhuang P, McBride MB, Xia H (2009) Health risks from heavy metals via consumption of food crops in the vicinity of Dabaoshan mine, South China. Sci Total Environ 407(5):1551-1561

Publisher's Note Springer Nature remains neutral with regard to jurisdictional claims in published maps and institutional affiliations. 